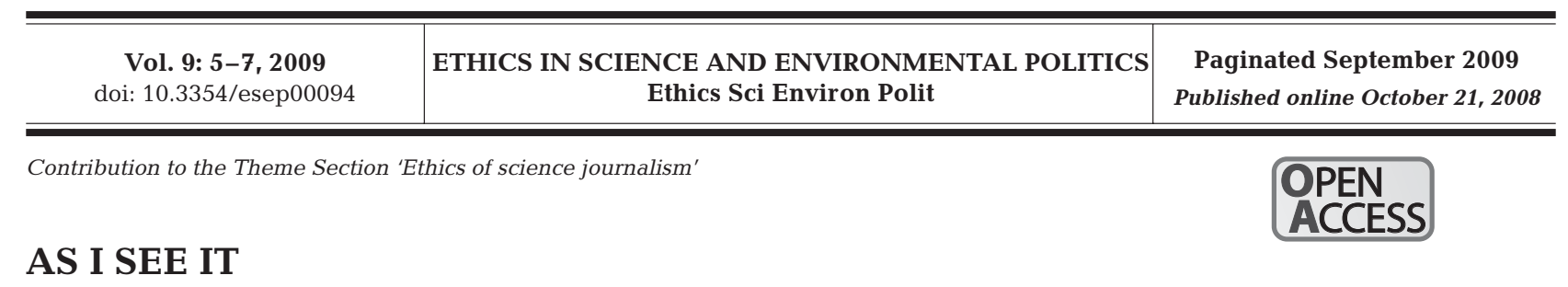

\title{
Is science reporting turning into fast food?
}

\author{
Michael Gross* \\ School of Crystallography, Birkbeck College London, Malet Street, London WC1E 7HX, UK
}

\begin{abstract}
I have been writing about scientific progress - first as a night-time hobby journalist and then as a full-time freelance writer - for 15 years. While we are immersed in such an occupation, it is difficult to see it evolving and to assess shifting norms and boundaries. I have recently had the opportunity to reflect on how much science reporting has changed during that time span, and what the possible impact of modern forms of communication, such as blogging, may be. I have observed that the competition for readers' attention and the general acceleration of communications has restricted the range of scientific subjects that can be reported. Only topics that can be presented in a tempting light and easily digested tend to survive, replacing food for thought with a more superficial mental diet.
\end{abstract}

KEY WORDS: Science journalism $\cdot$ Public understanding of science $\cdot$ Media $\cdot$ Science Magazines Resale or republication not permitted without written consent of the publisher

\section{INTRODUCTION}

For the last 15 years, I have been writing about scientific progress - first as a night-time hobby journalist, to relax from the stress of scientific research, and then as a full-time freelance writer, trying to make a living from my former hobby. While we are immersed in such an occupation, it is difficult to see it evolving and to assess shifting norms and boundaries. However, I have recently had the opportunity to compile a collection of my favourite science stories from the last $15 \mathrm{yr}$ (Gross 2008a), which has also given me the chance to observe and reflect on how much science reporting has changed during that time span.

\section{NEWSPAPERS: THE ERA OF THE WEEKLY SCIENCE SECTION}

When I started writing for newspapers in 1993, science tended to be covered in weekly pullout-sections. I first wrote for the Süddeutsche Zeitung in Germany, later also for several other papers including the Berliner Zeitung and Die Welt in Germany, and The Guardian and The Independent in the UK. All of them had a weekly science supplement at least at some point.
The weekly format enabled me to identify a topic that I considered relevant and prepare a fairly detailed article about it, with deadlines on the timescale of a week. A typical length for Süddeutsche Zeitung was 150 lines, or around 750 words. My first published piece was about the crystal structure of nitrogenase, the enzyme that allows bacteria to convert the nitrogen from the air into ammonia, which can be used in biochemical reactions (Gross 1993). Today, I cannot think of any non-specialist publication that would let me get away with 750 words about such a demanding topic.

In the UK, in the mid-1990s, The Guardian came up with the science and technology pull-out called 'online'. This section started out with what I considered a very good coverage of science, and it also offered a lively forum where scientists contributed to the debates on science and society, such as the 'two cultures' question, and the infamous Sokal affair (http:// en.wikipedia.org/wiki/Sokal_affair).

In 'online', I published a few science features on topics including camel antibodies (Gross 2000) and the sensory system involved when we feel the urge to urinate. With the expansion of the first internet bubble (the boom of the first dotcom companies), 'online' was gradually taken over by technology and internet issues, leaving less space for science reporting. 
In 2003, i.e. after the bubble had burst, 'online' was replaced by a new pullout called 'Life', which The Guardian published in association with Nature magazine. Here science found a home again on up to 10 tabloid-sized pages, which also covered environment, medicine, and technology (and, most importantly, the science of The Simpsons, see Gross 2003). I understand that 'Life' was a favourite project of The Guardian editor, Alan Rusbridger, who felt inspired by the human genome revolution and sincerely wanted to give science more weight within the paper.

A few years later, however, this new 'Life' form died off as well. Insiders cite the lack of interest from advertisers and the switch to the Berliner format as factors contributing to its demise, which left science to fend for itself among the daily stream of news. According to the announcement made when the format changed, there should now be a page (half of which may be advertising) for science every day, but when browsing through the paper I often reach the back pages without having noticed the page that was supposedly dedicated to science. The page isn't always labelled as 'science', and the main story may be of a fairly general nature (e.g. about medical provision), so I can only identify the science page by some small piece at the bottom which I may have overlooked in the first browsing.

While the paper tried to sell the move as a promotion for science, out of the ghetto and into the real world, I got the impression that less of it made the cut, as much of the daily 'science' page is dominated by material that is newsy all right, but not very relevant by scientific criteria.

Only very occasionally does a science feature make it into the feature section, into the weekend magazine, or into the 'technology' pullout, which thanks to the advertising revenue survived the tribulations. For the paper's full-time science, technology, and medicine correspondents this means that they have to prepare stories speculatively, hoping they will survive the competition against other news stories. And recent news suggests that at least one serious national newspaper in the UK may stop employing a science correspondent altogether.

For me as a freelance science reporter, the abolition of the weekly science reporting means that I cannot afford to write for newspapers, as I need time and some kind of security. For the reader, I think it means that they lose out on finding out what science has to offer culturally, on all the creative things that scientists do but which aren't necessarily newsy enough to merit space in the front section of a newspaper.

Often it is the obscure, not very newsworthy research that can become big news very quickly, as happened to the retroviruses at the beginning of the AIDS epidemic, or to RNA interference at the point when it was found to be both a universal phenomenon and a valuable tool for postgenomic research. Only a broad science reporting not enslaved by the news agenda can educate readers about what may become important tomorrow.

\section{MONTHLY MAGAZINES}

Since the demise of the weekly newspaper science supplement I have focused on working for magazines, including monthlies like Spektrum der Wissenschaft (the German edition of Scientific American), Chemistry in Britain and its successor Chemistry World, and the biweekly publication Current Biology.

In this domain, there is still space for detailed science features, ranging from the 800 word one-pager to a full length 2500 word feature.

The news reporting of the monthlies, however, has also been affected by the general rush towards 'fast food' reporting. Chemistry World now publishes news online as fast as possible. With stories based on papers in the leading scientific journals such as Nature and Science, which typically come with an embargoed advanced press release, the Chemistry World news team aim at putting their story online the very minute the embargo is lifted.

For us contributors, this means that we have 3 days to pitch a topic to the editors, talk to the scientists involved and to at least one independent expert, and to write it up and submit it. At this rate it is inevitable that the reporting loses depth, and errors may creep in. If we spot flaws in the original research, we often don't have time to go to the bottom of the issue (Gross $2008 b, c)$. It is also becoming more difficult to generate a steady and reliable income from this type of work.

Thus, my impression is that science reporting, both in the newspaper and in the magazine market, is gradually losing depth and relevance due to the general acceleration of the process and the competition to present headline-grabbing material before everybody else. Science reporting is being turned into fast food.

\section{IMPACT OF BLOGGING}

Part of the reason behind the general acceleration is of course the blogging revolution, brought upon us by millions of individuals who provide instant news and comment in their personal weblogs. Nowadays, we expect to read about news as soon as it happens, both via the online presence of established newspapers and via the grassroots movement of the blogs.

However, I would argue that science magazines should not feel the impact of blogging as much as other 
sections of the media market, as only a surprisingly small number of scientists blog directly from the front lines of research. Most research scientists prefer to get on with their lab work until the point when they can write it up in a paper or conference communication and shun the informal communication channels such as blogging.

Science magazines have gone with the times and set up their own blogs, but from my perspective it appears to me that blogs are useful in directing attention towards important papers or reports, but that they will not replace traditional science reporting. In my own blog (www.proseandpassion.com), for instance, I provide roughly equal numbers of short, original 'science news' items and links to my science journalism pieces published in magazines.

\section{HOW DO THE CHANGES AFFECT WHAT IS BEING REPORTED?}

The 'fast food' trend, as described above, constrains the range of science topics that can be reported in newspapers and magazines. Highly complex issues that require a fair amount of explanatory background will be less likely to be reported at all. For example, simplistic 'scientists found a gene for trait $\mathrm{X}$ ' stories get overrepresented, while the truth about the real complexity of the genome, e.g. the role of histones, nongene DNA, and other epigenetic elements, is underreported.

To make matters worse, the fact is that the knowledge life scientists uncover is intrinsically more complex than it was a couple of decades ago. In the 1980s and early 1990s, the reductionist approach to biology

Editorial responsibility: Virginia Burkett, Many, Louisiana, USA was still in full swing. Researchers characterised one gene or one protein and drew conclusions from that. Now, with many complete genomes available in searchable databases, biology has moved on towards higher levels of complexity. Researchers now look at complex regulatory systems linking many genes and many proteins. Ideally, they want to understand cellular or even organismal responses at the level of the whole system, hence the term 'systems biology' which describes this movement.

This change necessarily makes scientific results more complex and more difficult to explain to lay readers. Rather than shrinking science reporting into ever faster and shorter snippets, we should look at ways in which we can invest more time and space into explaining to the general public the more demanding, but also more rewarding, insights that science is obtaining now.

\section{LITERATURE CITED}

Gross M (1993) Ungelöstes Rätsel Ammoniak-Synthese-Die perfekte Technik der Natur wird jetzt ein bißchen besser verstanden. Süddeutsche Zeitung Nr 16, 21 January 1993, p 30

Gross M (2000) One reason to get the hump. The Guardian 'online', 14 September 2000, p 2-3

Gross M (2003) Eat my lab coat. The Guardian LIFE, 30 October 2003, p 9

Gross M (2008a) The birds, the bees, and the platypuses. Crazy, sexy and cool stories from science. Wiley-VCH, Weinheim

Gross (2008b) Ice-cream without the crunch. Chemistry World, 14 January 2008. Available at: www.rsc.org/ chemistryworld/ News/2008/January/14010801.asp

Gross (2008c) Chemical wheel could boost computers. Chemistry World, 11 March 2008. Available at: www.rsc. org/chemistryworld/News/2008/March/11030802.asp

Submitted: August 21, 2008; Accepted: October 9, 2008

Proofs received from author(s): October 20, 2008 